\title{
NALAZI KAMENOG CRKVENOG NAMJEŠTAJA IZ CRKVE SV.STEFANA U GOLUBIĆU KOD KNINA
}

\begin{abstract}
Autor u radu donosi prvu objavu i obrađuje ulomke kamenog crkvenog namještaja iz crkve sv. Stefana u Golubiću kod Knina pronađene pri radovima na njezinu uređenju 2009., 2010., 2014. i 2015. godine. Dosad je iz te crkve bio poznat samo jedan ulomak arhitrava ograde svetišta koji se okvirno datirao u 9. stoljeće. Novopronađenih šest ulomaka pruža mogućnost preciznijih datacija njezina nastanka i obnove. Najstarija faza povezana je s ranokršćanskim razdobljem, nakon čega slijede zasigurno dvije predromaničke faze od kojih je prva povezana s tzv. Trogirskom klesarskom radionicom i prvom četvrtinom 9. stoljeća, dok se druga može pripisati tzv. Benediktinskoj klesarskoj radionici iz vremena kneza Branimira, tj. zadnjoj četvrtini 9. stoljeća.

Ključne riječi: Golubić; crkva sv. Stefana; Trogirska klesarska radionica; Benediktinska klesarska radionica iz vremena kneza Branimira; rano kršćanstvo; predromanika.
\end{abstract}

\section{UVOD}

Tijekom studenoga i prosinca 2009. te početkom 2010. godine obavljeni se radovi na obnovi dijelova pravoslavne crkve sv. arhiđakona Stefana u selu Golubiću (slika 2) koji se nalazi oko 9 km sjeverno od Knina (slika 1). Obuhvaćali su sondiranje i otucanje žbuke sa zidova u unutrašnjosti crkve i njihovo ponovno žbukanje. Također je obavljena sanacija pročelja crkve sa zvonikom, žbuke i kamenih okvira na njemu. Radove je izvodila tvrtka Krševan d.o.o. iz Zadra, a financirala ih je I. Kninska parohija. Pri radovima u unutrašnjosti crkve otkrivena su četiri ulomka predromaničkoga kamenog crkvenog namještaja koji su nakon što su izvađeni iz zidova preneseni $u$ radionicu navedene tvrtke u Crno kod Zadra, gdje su očišćeni i konzervirani. U međuvremenu je tvrtka otišla u stečaj, a ulomci su ostali u radionici koja je ostavljena u zapuštenom stanju, a njezin je okoliš zarastao u korov. U istom prostoru nalazio se niz ulomaka ranokršćanskoga kamenog namještaja s lokaliteta Podvršje - Glavčine koje sam kao voditelj istraživanja tamo dopremio na konzervaciju i restauraciju. Vlasnik prostora do- 
pustio mi je ulazak u radionicu i pomogao mi otpremiti ranokršćanske nalaze koji su se nalazili u dvorištu, te me upozorio da u unutrašnjosti radionice ima još nekoliko ulomaka koje bi također trebalo odnijeti jer namjerava preurediti cjelokupni prostor. Među tim predmetima bila su i tri ulomka pronađena pri radovima na obnovi crkve sv. Stefana u Golubiću (slike 4, 6, 9), koje sam zajedno s ostalim nalazima u lipnju 2017. dopremio u Arheološki praktikum Odjela za arheologiju Sveučilišta u Zadru. U kontaktu s nekadašnjim djelatnicima tvrtke Krševan d.o.o. došao sam do saznanja o vremenu i okolnostima nalaza, a osobitu pomoć pri svemu pružio mi je restaurator Silvije Pranjić, danas djelatnik tvrtke Travej d.o.o. iz Zadra. On mi je ustupio i dvadesetak fotografija na kojima su svi pri radovima pronađeni nalazi kamene plastike pojedinačno fotografirani (sveukupno četiri), a neki od njih i na mjestu gdje su bili ugrađeni u zidove, te nakon njihova vađenja i pripreme za transport u radionicu. ${ }^{1}$ Među tim nalazima bio je i ulomak arhitrava ograde svetišta (slika 11), koji je donesen u radionicu i očišćen, međutim u međuvremenu je izgubljen.

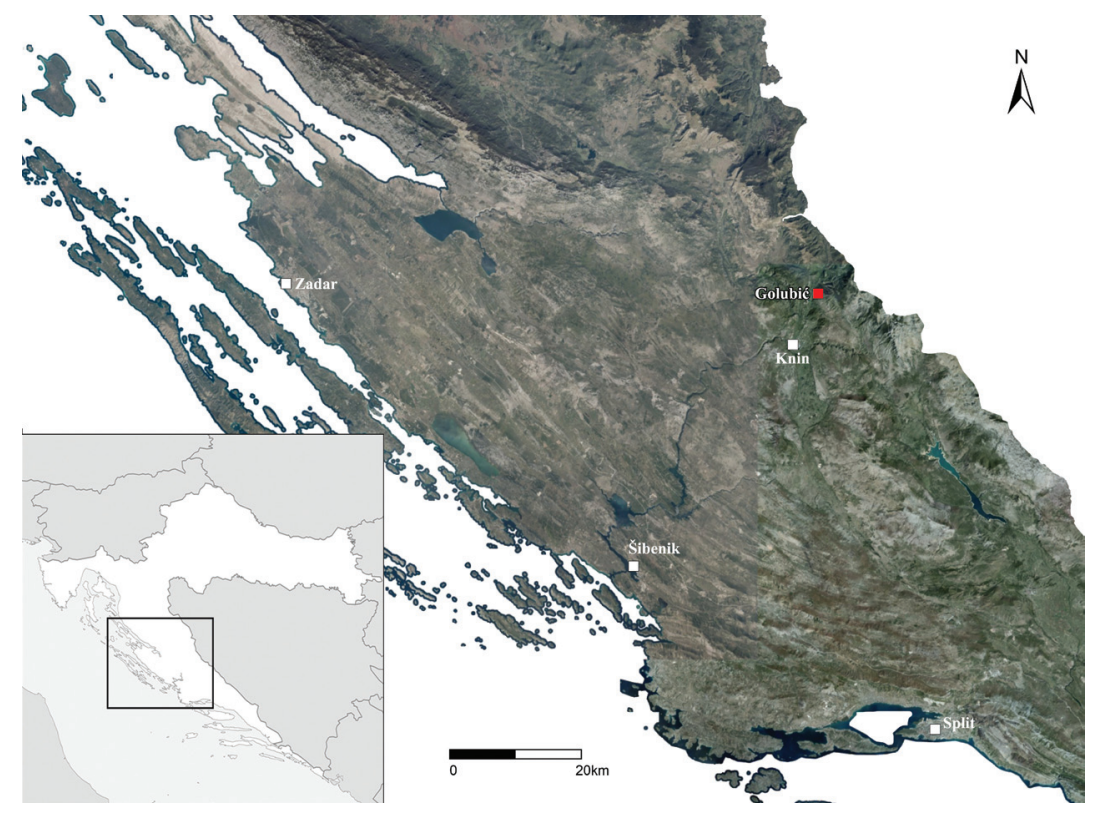

Slika 1. Topografska karta s naznačenim položajem naselja Golubić (izradio J. Šućur)

$\overline{1}$ Od srca zahvaljujem kolegi Silviju Pranjiću na podatcima o nalazima i ustupljenoj fotodokumentaciji. Zahvalnost na pomoći dugujem još restauratoru Šimi Glavanu, i danas djelatniku tvrtke Travej d.o.o. Svi ulomci kamenog crkvenog namještaja iz zidova su izvađeni tijekom studenoga i prosinca 2009. 


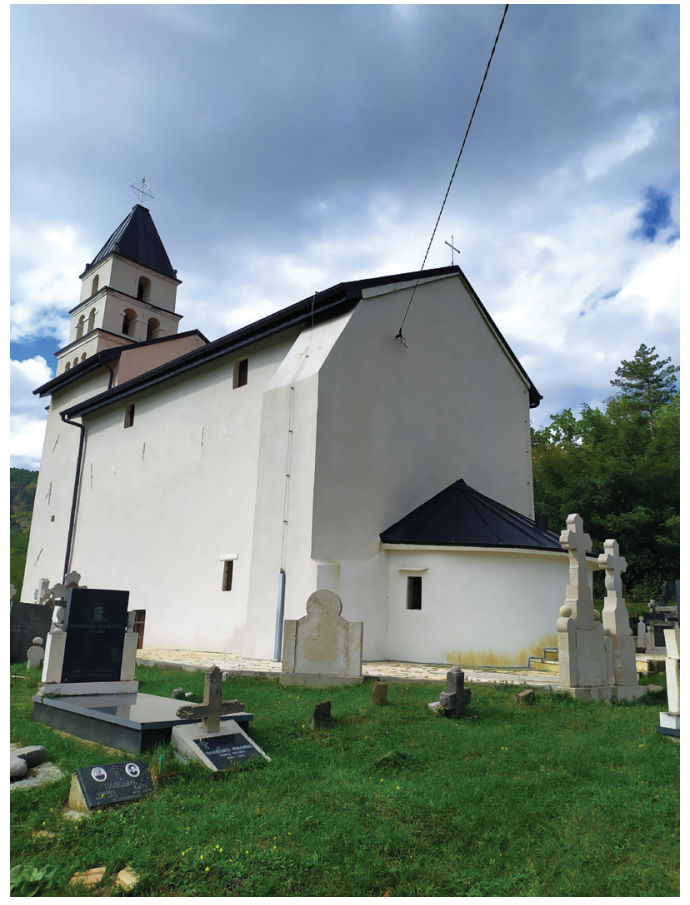

Slika 2. Crkva sv. arhiđakona Stefana u Golubiću (foto: K. Gugo)

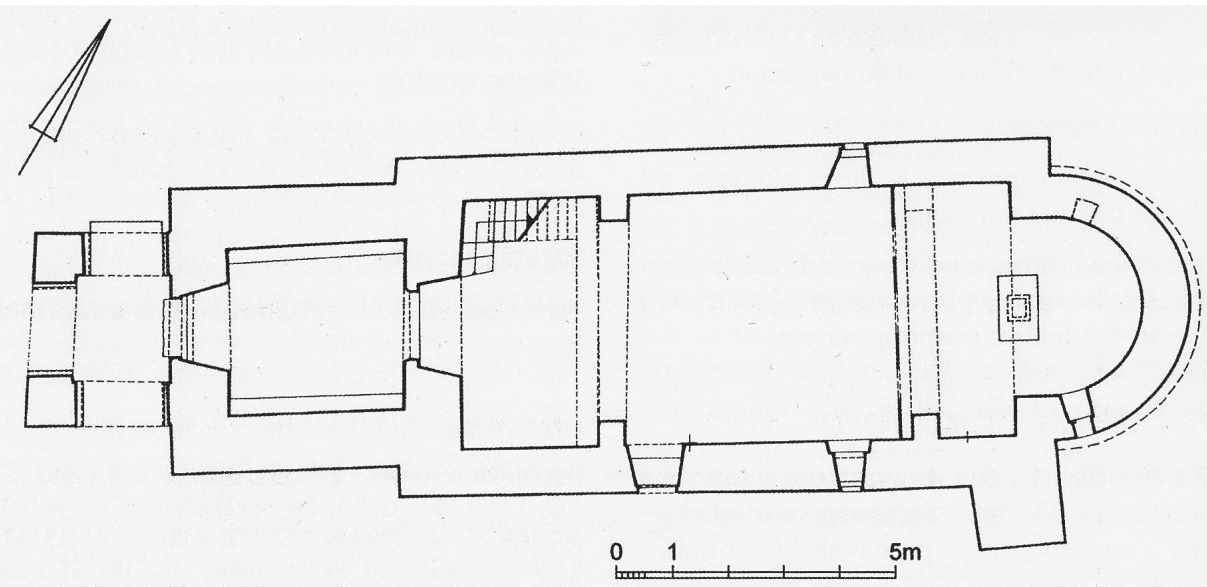

Slika 3. Tlocrt stanja crkve u Golubiću 1987. (izvor: T. Marasović, Dalmatia praeromanica, 492, sl. 597) 
Novi radovi na crkvi sv. Stefana u Golubiću uslijedili su tijekom 2014. i 2015. godine, a izvodili su ih sami mještani. Financirala ih je i I. Kninska parohija pod nadzorom nadležnog paroha. Tada je crkva dobila i sadašnji izgled. Radove je uime Konzervatorskog odjela u Šibeniku nadzirao dr. sc. Marko Sinobad, konzervator s toga odjela, koji je u Kninski muzej na pohranu dostavio dva u toj prigodi pronađena ulomka predromaničkoga kamenog crkvenog namještaja. Jedan od njih jest ulomak pluteja (slika 8) koji se nalazi u Kninskom muzeju, dok se drugom za koji nije sigurno čemu pripada (slika 12), nije u ovom trenutku moglo ući u trag u istom muzeju. ${ }^{2}$

Treba istaknuti da je u znanstvenoj i stručnoj literaturi iz crkve sv. Stefana u Golubiću dosad bio izgledom poznat samo jedan ulomak predromaničkog kamenog crkvenog namještaja, ulomak arhitrava s posvetnim natpisom [...sancta] E MARIE[...] uočen i objavljen još tijekom druge polovice 19. stoljeća (slika 10), koji je kao spolij bio ugrađen u prag južnih vrata te crkve. ${ }^{3}$ Ulomke kamene plastike ugrađene u zidove crkve uočio je i fra Lujo Marun pri obilasku crkve 1927. godine ${ }^{4}$ koji navodi da se radi o dva ulomka pluteja, ugrađena nad glavnim i bočnim vratima i ukrašena palmetama ispod križa. Jedan veći ulomak ukrašen pleternom ornamentikom bio je uzidan na pročelju zvonika. Od vidljivih ulomaka navodi i naprijed spomenuti ulomak arhitrava ograde svetišta s posvetnim natpisom. Iz navedenog opisa razvidno je da je vjerojatno riječ o barem dva ulomka kamene plastike izvađena iz zidova u radovima 2009.

2 Podatke o tim nalazima i njihove fotografije nesebično mi je ustupila mr. sc. Katarina Gugo, viša kustosica Arheološke zbirke Kninskog muzeja, kojoj na svemu naiskrenije zahvaljujem.

3 F. Bulić, Hrvatski spomenici u kninskoj okolici uz ostale suvremene dalmatinske iz doba hrvatske narodne dinastije, 1, Zagreb 1988, T. IV, 11. Za ostalu literaturu vidi popis uz opis ulomka crkvenog namještaja pod rednim brojem 5. Ulomak je 1995. godine izvađen s mjesta gdje je izvorno stajao i pohranjen je u Muzej hrvatskih arheoloških spomenika u Splitu te zamijenjen kopijom.

4 L. Marun, Starinarski dnevnici, (prir.) Maja Petrinec, Split, 1998, 286, nadnevak 6. lipnja 1927. 


\section{OPIS NALAZA}

1. Ulomak pluteja (slike $4-5$ ). Sačuvan je donji dio uskog pluteja koji je unutar okvira od glatkih letvi imao ukras latinskog križa s glatkim hastama proširenim na krajevima te palmetama ispod vodoravnih hasti. Na lijevoj bočnoj strani pluteja sačuvano je rebro za uglavljivanje na pilastar.

Materijal: vapnenac.

Dimenzije: dužina $34,5 \mathrm{~cm}$, visina $29 \mathrm{~cm}$, debljina $12 \mathrm{~cm}$.

Smještaj: Arheološki praktikum Odjela za arheologiju Sveučilišta u Zadru.

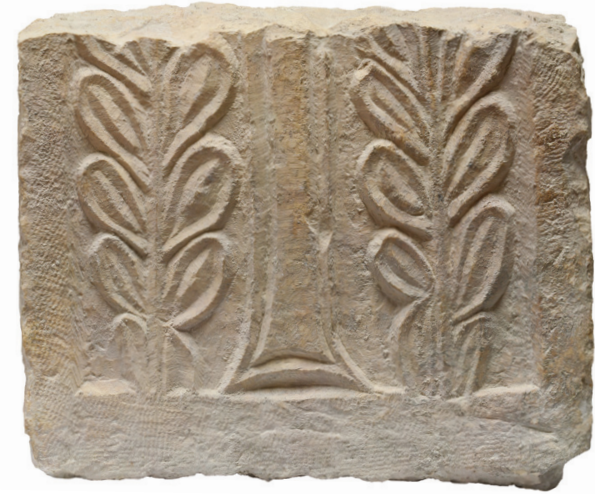

Slika 4. Ulomak pluteja ukrašen palmetama pod latinskim križem (foto: M. Parica)

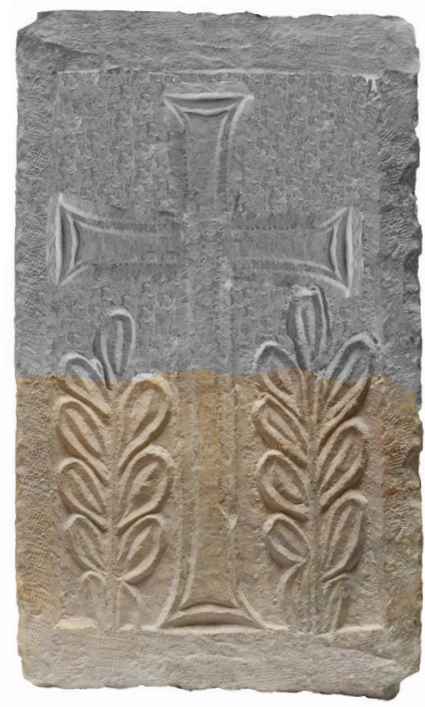

Slika 5. Djelomična rekonstrukcija izgleda pluteja s palmetama ispod križa (izradio: L. Bogdanić) 
2. Ulomak pluteja (slika 6). Sačuvana je otprilike polovica glavnog ukrasnog polja uokvirenog letvama na kojem je uklesan motiv dviju palmeta smještenih pod latinskim križem unutar arkade. Luk arkade ispunjen troprutom pletenicom u donjem dijelu naliježe na dva stupića (ispunjena troprutom pletenicom) sa stiliziranim kapitelima. I haste križa ispunjene su troprutim pletenicama, a svi njegovi krakovi šire se na krajevima. Iznad vodoravne haste nalaze se dvije virovite rozete. U gornjem kutu iznad arkade ukomponiran je stilizirani cvijet ljiljana. Na desni stupić s kapitelom nastavljala se druga arkada, pa se može pretpostaviti da je i desna strana pluteja bila identična lijevoj te da se na kutu iznad desne arkade nalazio također ukras oblika stiliziranog cvijeta ljiljana, a taj se ukras najvjerojatnije nalazio i između spoja lukova arkada (slika 7).

Materijal: vapnenac.

Dimenzije: dužina $67 \mathrm{~cm}$, visina $69 \mathrm{~cm}$, debljina $14 \mathrm{~cm}$.

Smještaj: Arheološka zbirka Odjela za arheologiju Sveučilišta u Zadru.

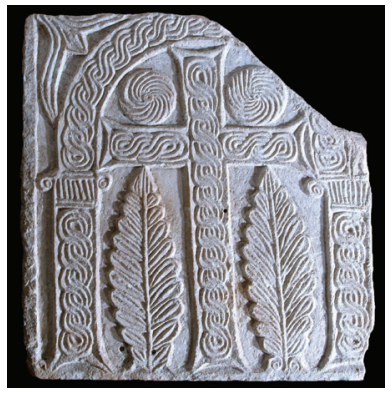

Slika 6. Ulomak pluteja s ukrasom dviju palmeta pod latinskim križem unutar arkade (foto: M. Parica)

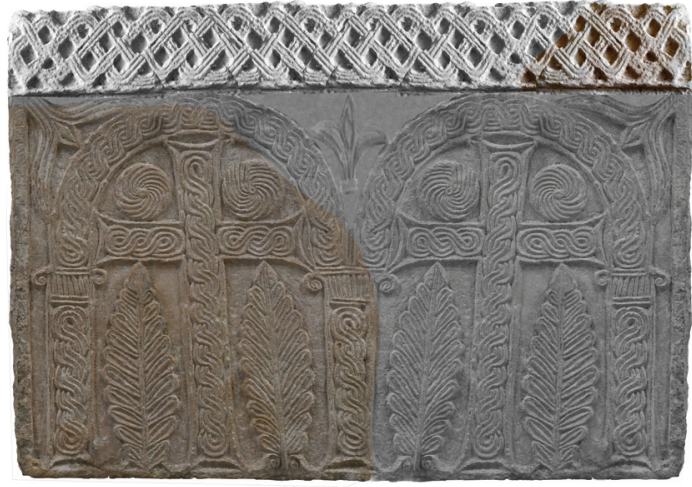

Slika 7. Idejna rekonstrucija pluteja iz Golubića (izradio: L. Bogdanić) 
3. Ulomak pluteja (slika 8). Sačuvan je gornji desni dio pluteja čija je dekorativna ploha bila podijeljena na glavno polje i reljefno istaknutiji vijenac na gornjem dijelu. Vijenac su sa svih strana uokvirivale neprofilirane rubne letve, a ispunjavalo ga je gusto mrežište izvedeno od prepleta troprute trake. Glavno je polje, kao kod prethodno opisanog, bilo ispunjeno motivom palmeta smještenih pod latinskim križem unutar arkade. Preostao je samo mali dio arkade ispunjene troprutom pletenicom i dio stiliziranog ljiljanova cvijeta koji se nalazio iznad arkade. Sačuvan je i dio rebra za uglavljivanje na pilastar.

Materijal: vapnenac.

Dimenzije: dužina $45 \mathrm{~cm}$, visina $34 \mathrm{~cm}$, debljina $12-14 \mathrm{~cm}$.

Smještaj: Kninski muzej, Knin, inv. br. 510:KNI-112-A-KS.

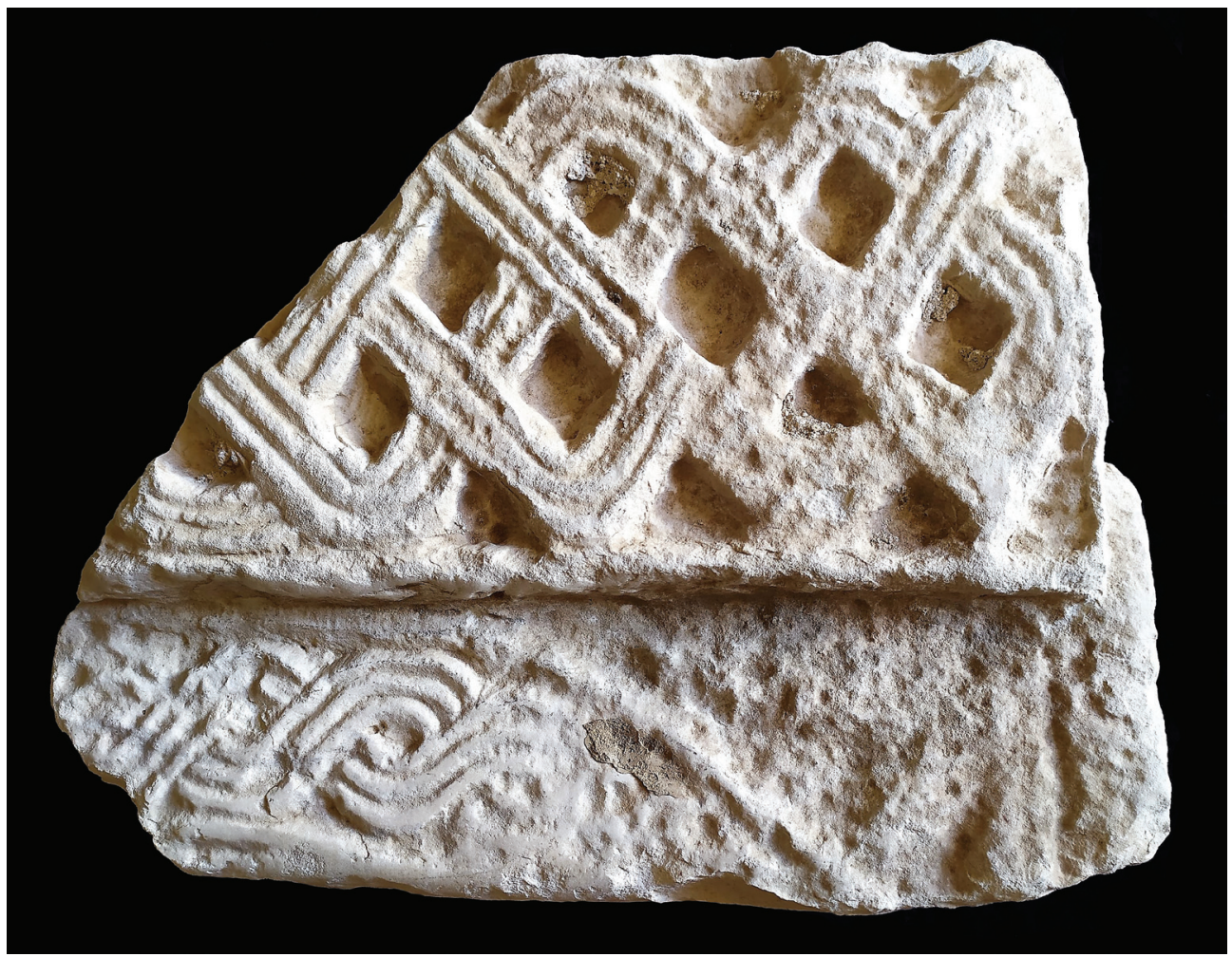

Slika 8. Ulomak pluteja ukrašen gustim prepletom s ostatkom arkade na donjem dijelu (foto: K. Gugo) 
4. Ulomak pilastra, vrlo oštećen, ukrašen četveroprutim gustim prepletom, otučen sa svih strana (slika 9).

Materijal: vapnenac.

Dimenzije: dužina $18 \mathrm{~cm}$, visina $17,5 \mathrm{~cm}$, debljina $16 \mathrm{~cm}$.

Smještaj: Arheološki praktikum Odjela za arheologiju Sveučilišta u Zadru.

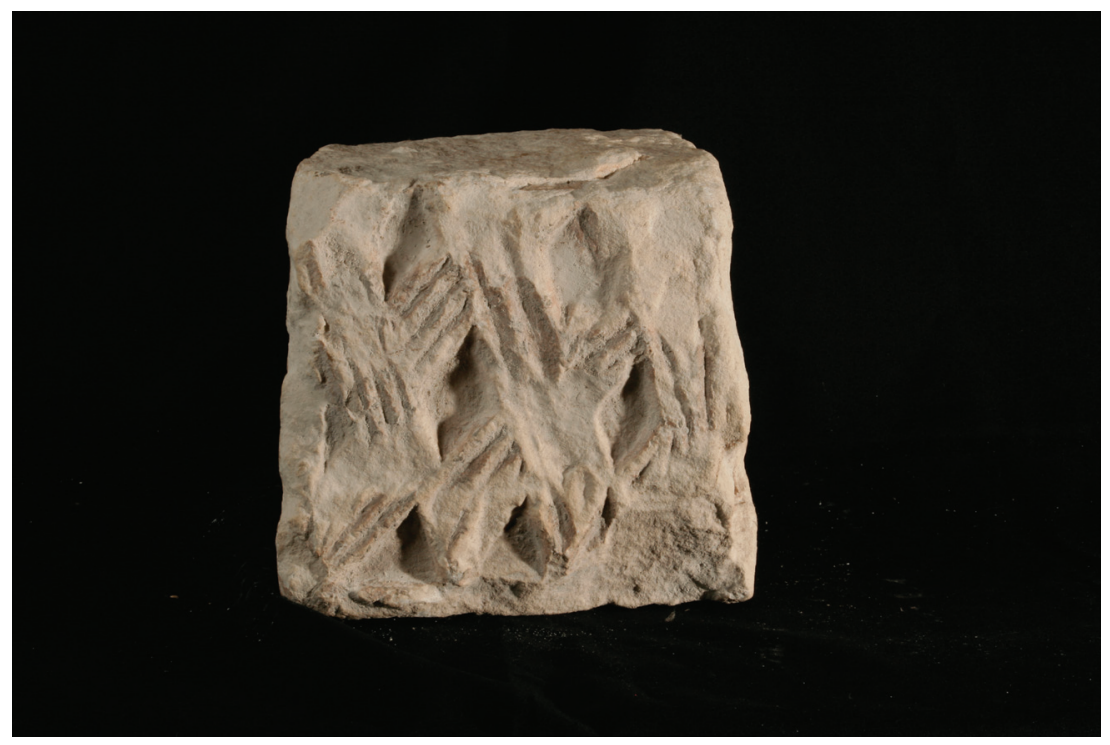

Slika 9. Ulomak pilastra s četveroprutim prepletom (foto: M. Parica)

5. Ulomak arhitrava ograde svetišta (slika 10). Zbog naknadne ugradnje u prag vrata novovjekovne crkve prednja mu je ploha jako izlizana. Njezina površina kompozicijski je sastavljena od dva pojasna polja, na gornjem se nalaze kuke s dvoprutom nožicom, dok je na donjem dio posvetnog natpisa [... sancta]E MARIE[...].

Materijal: vapnenac.

Dimenzije: dužina 40,5 cm, visina $17 \mathrm{~cm}$, debljina $15 \mathrm{~cm}$, visina natpisnog polja $7,5 \mathrm{~cm}$.

Smještaj: Muzej hrvatskih arheoloških spomenika, Split, inv. br. 2601.

Literatura: F. Bulić, Hrvatski spomenici u kninskoj okolici uz ostale suvremene dalmatinske iz doba hrvatske narodne dinastije, 1, Zagreb, 1888, T. IV, 11; L. Marun, Ruševine crkve Sv. Luke u Uzdolju kod Knina s pisanom uspomenom hrv. kneza Mutimira, Starohrvatska prosvjeta, n.s., 1, 3-4, Zagreb - Knin, 1927, 306307; S. Gunjača, Trogodišnji rad Muzeja hrvatskih arheoloških spomenika 
(1955., 1956. i 1957. godine), Starohrvatska prosvjeta, III. s., 7, Zagreb, 1960, 275; M. Budimir, Arheološka topografija kninske općine, Izdanja Hrvatskog arheološkog društva, 15/1990. (Arheološka istraživanja u Kninu i kninskoj krajini, Znanstveni skup, Knin, 13.-15. X. 1987.), Zagreb, 1992, 29; V. Delonga, Latinski epigrafički spomenici u ranosrednjovjekovnoj Hrvatskoj, Split, 1996, 187, 317, T. LXI, 155; Z. Demori Staničić, L'eglise Saint-Etieenne de Golubić, Hortus Artium Medievalium, 4, Zagreb - Motovun, 1998, 223, 225, sl. 7; L. Marun, Starinarski dneonici (prir.) Maja Petrinec, Split, 1998, 286; N. Jakšić, Klesarstvo u službi evangelizacije, u: Hrvati i Karolinzi - Rasprave i vrela, (ur.) Ante Milošević, Split, 2000, 206; A. Milošević, Nove akvizicije Muzeja hrvatskih arheoloških spomenika od 1995. do 2000. godine, Starohrvatska prosvjeta, III. s., 27, Split, 2000, 316; V. Delonga - N. Jakšić - M. Jurković, Arhitektura, skulptura i epigrafika karolinškog doba u Hrvatskoj, Split, 2001, 46; N. Jakšić, Scultura e liturgia, u: Bizantini, Croati, Carolingi. Alba e tramonto di regni e imperi, (ur.) Carlo Bertelli et alii, Milano, 2001, 188; Isti, Reljefi Trogirske klesarske radionice iz crkve Sv. Marte u Bijaćima, Starohrvatska prosvjeta, III. s., 26/1999., Split, 2004, 271; T. Marasović, Dalmatia praeromanica: ranosrednjovjekovno graditeljstvo u Dalmaciji - 2. Korpus arhitekture: Kvarner i sjeverna Dalmacija, Split - Zagreb, 2009, 492, 494-495, sl. 603; A. Milošević - Ž. Peković, Predromaniĉka crkva Svetoga Spasa u Cetini, Dubrovnik - Split, 2009, 167, bilj. 312; I. Josipović, Prilog Trogirskoj klesarskoj radionici, Ars Adriatica, 1, Zadar, 2011, 105, bilj. 2; Isti, Predromanički reljefi na teritoriju sklavinije Hrvatske između Zrmanje i Krke do kraja 9. stoljeća, doktorski rad, 1. dio, Zagreb, 2013, 655-656; Isti, Predromanički reljefi na teritoriju sklavinije Hrvatske između Zrmanje i Krke do kraja 9. stoljeća, doktorski rad, 2. dio, Zagreb 2013, 134, 2.1; N. Jakšić, Klesarstvo u službi evangelizacije. Studije iz predromaničke skulpture na Jadranu, Split, 2015, 93, 273.

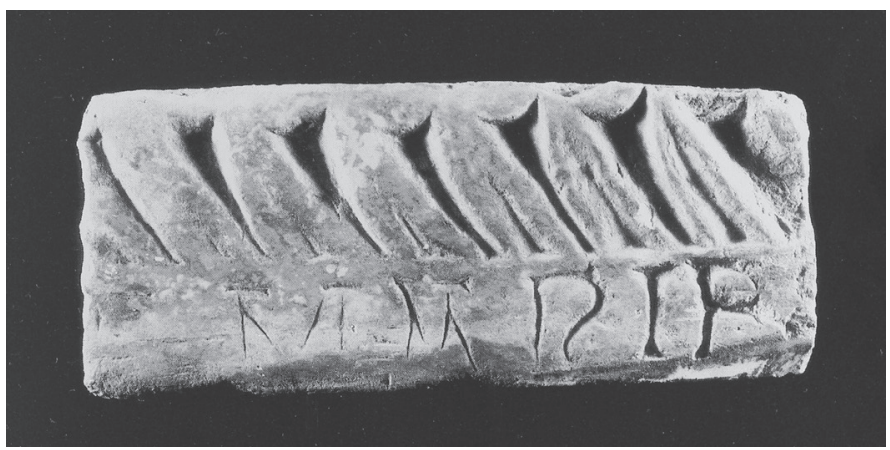

Slika 10. Ulomak arhitrava ograde svetišta s posvetnim natpisom [...sancta]E MARIE[...]. Izvor: V. Delonga, Latinski epigrafički spomenici, 317, T. LXI, 155) 
6. Ulomak arhitrava ograde svetišta, vrlo oštećen i sa svih strana otučen (slika 11). Najvjerojatnije se radilo o arhitravu s ukrasnom kompozicijom podijeljenom u tri pojasa. Gornje ukrasno polje bilo je ispunjeno jednostrukim kukama. Središnjim poljem tekao je niz troprutih petlji. Donje je polje otučeno, a na njemu se najvjerojatnije nalazio posvetni natpis.

Materijal: vapnenac.

Dimenzije: dužina $29 \mathrm{~cm}$, visina $18 \mathrm{~cm}$.

Ulomak je izgubljen.

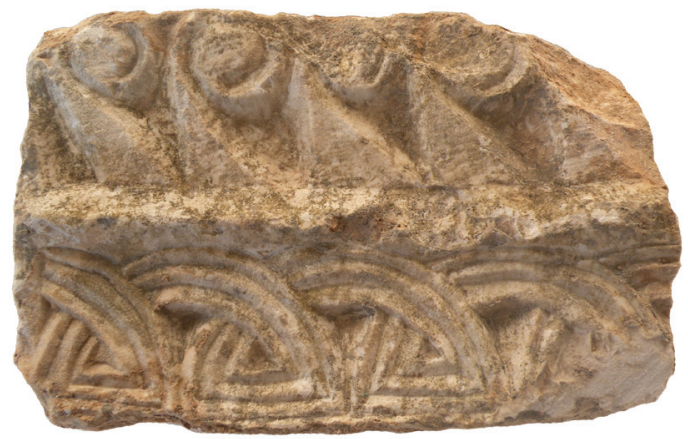

Slika 11. Ulomak arhitrava ograde svetišta ukrašen kukama i prepletom (foto: S. Pranjić)

7. Ulomak predromaničkog kamenog crkvenog namještaja neutvrđene namjene ukrašen troprutom pletenicom (slika 12).

Materijal: vapnenac.

Dimenzije: nisu poznate.

Smještaj: Kninski muzej, Knin.

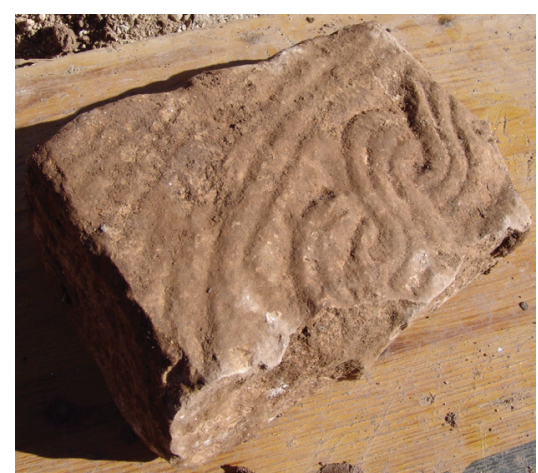

Slika 12. Ulomak kamenog crkvenog namještaja ukrašen troprutom pletenicom (foto: M. Sinobad) 


\section{RASPRAVA S INTERPRETACIJOM NALAZA}

Naselje Golubić nalazi se na području srednjovjekovnog sela Butina Vas. Prvi spomen naselja pod tim imenom u izvornoj je građi poznat iz 1368. godine, kada se navodi kao posjed kninskog biskupa. ${ }^{5} \mathrm{Na}$ temelju već spomenutog sačuvanog posvetnog natpisa s arhitrava ograde svetišta [...sancta]E MARIE[...] argumentirano se pretpostavljalo da je u srednjem vijeku tamo bila značajna crkva posvećena Bogorodici. ${ }^{6}$ Prema kontinuitetu kulta pretpostavljeno je također da je sunaslovnik crkve bio sv. Stjepan, koji se spominje u crkvenim knjigama kao Sancti Stephani in suburbio, te da je taj titular zadržan i nakon prelaska crkve pod pravoslavnu jurisdikciju. ${ }^{7}$ Zoraida Demori Staničić prva se detaljnije upustila u analizu arhitekture crkve sv. Stefana (slika 3). Ona je iznijela mišljenje da je ta crkva naslijedila strukturu predromaničke građevine s tzv. westwerkom, te je također pretpostavila njezino ranokršćansko podrijetlo. ${ }^{8}$ Njezinim tragom išli su i Željko Peković i Ante Milošević, koji su izradili idejnu rekonstrukciju izgleda crkve i osobito istaknuli činjenicu da ona svojim proporcijama gotovo u potpunosti odgovara crkvi sv. Spasa na vrelu Cetine. ${ }^{9}$

Nalazi kamenog crkvenog namještaja pronađeni u crkvi sv. Stefana u Golubiću pri njezinoj obnovi u razdoblju 2009. - 2015., mada relativno malobrojni, pružaju mogućnost preciznije datacije faza nastanka i obnove crkve, a ujedno potvrđuju pojedine naprijed istaknute dosadašnje pretpostavke o tome.

Detaljnom analizom pronađenih ulomaka i onog jedinog dosad poznatog ulomka arhitrava s ostatkom posvetnog natpisa dolazimo do rezultata o elementima triju različitih faza. Najstariji je ulomak pluteja s ukrasom palmeta ispod latinskog križa (slika 4). S obzirom na veličinu pluteja i način obrade ikonografskog prikaza, sve navodi na činjenicu da se radi o ranokršćanskom ulomku. Da bi se dobio bolji vizualni dojam, pokušali smo napraviti i njegovu djelomičnu rekonstrukciju (slika 5).

5 F. Smiljanić, Građa za povijesnu topografiju kninsko-drniškoga kraja u srednjem vijeku, Izdanja Hrvatskog arheološkog wdruštva, 15/1990. (Arheološka istraživanja u Kninu i kninskoj krajini, Znanstveni skup, Knin, 13. -15. X. 1987.), Zagreb, 1992, 56.

6 V. Delonga, Latinski epigrafički spomenici u ranosrednjovjekovnoj Hrvatskoj, Split, 1996, 187.

7 T. Marasović, Dalmatia praeromanica: ranosrednjovjekovno graditeljstvo u Dalmaciji - 2. Korpus arhitekture: Kvarner i sjeverna Dalmacija, Split - Zagreb, 2009, 492.

8 Z. Demori Staničić, L'eglise Saint-Etieenne de Golubić, Hortus artium Medievalium, 4, Zagreb - Motovun, 1998, 223-229.

9 A. Milošević - Ž. Peković, Predromaniĉka crkva Svetoga Spasa u Cetini, Dubrovnik - Split, 2009, 167-169, A. Milošević, Predromaniĉki zvonici u Dalmaciji i ranosrednjovjekovnoj Hrvatskoj, Dubrovnik - Split, 2011, 63-64. 
Drugoj fazi zasigurno pripadaju četiri ulomka predromaničkog kamenog crkvenog namještaja koji se svojim ikonografskim karakteristikama mogu pripisati istom radioničkom krugu. To su dva ulomka pluteja (slike 6, 8), ulomak pilastra (slika 9) i ulomak grede ograde svetišta (slika 10) s ostatkom posvetnog natpisa [...sancta]E MARIE[...]. Oni se mogu pripisati tzv. Trogirskoj klesarskoj radionici, čije se djelovanje okvirno veže uz prvu četvrtinu 9. stoljeća. ${ }^{10}$ Ulomcima pluteja iz Golubića (slike 6,8) analogije nalazimo među primjercima pluteja iz Otresa kod Bribira, Kljaka kod Drniša, Pađena kod Knina te Trogira i Brnaza kod Sinja. ${ }^{11}$ Glavne karakteristike ukrasa tih pluteja očituju se u motivu dviju palmeta pod latinskim križem unutar arkade, a manifestiraju se kroz dva podtipa na način da jedni primjerci taj motiv imaju izveden preko čitave površine glavnog polja te su uži, dok je kod drugih isti motiv dupliciran, pa su takvi pluteji širi. Neki pluteji na vrhu su imali ukrasni vijenac ukrašen gustim prepletom troprute trake koji je bio istaknutiji u odnosu na glavno polje, dok drugi pluteji takve vijence možda nisu ni imali. Nalazi ulomaka pluteja iz Golubića omogućavaju idejnu rekonstrukciju jednog od pluteja ograde svetišta (slika 7).

Vrlo rustično i nevješto rađen ulomak pilastra znatno je oštećen, a bio je ukrašen četveroprutim gustim prepletom (slika 9). Mada je riječ o malom i vrlo otučenom ulomku, po svojim karakteristikama, odnosno gustom geometrijskom prepletu, on je vrlo srodan primjercima pilastara isklesanih u tzv. Trogirskoj klearskoj radionici, a koji potječu iz Otresa, Kljaka, Brnaza, Morinja u šibenskom Donjem polju i Bijaća kod Trogira. ${ }^{12}$ Razlika je jedino što se kod golubićkog primjerka javlja četveropruti preplet, dok se kod svih ostalih radi o troprutom prepletu.

$\overline{10}$ Tzv. Trogirsku klesarsku radionicu definirao je i imenovao Nikola Jakšić u svojoj doktorskoj disertaciji 1986. godine, a kasnije je o njoj u dva navrata objavio zasebni članak. Vidi: N. Jakšić, Kiparsko klesarske radionice u Dalmaciji od 9. do 12. stoljeća, doktorska disertacija, Zadar, 1986, 60-76; Isti, Reljefi Trogirske klesarske radionice iz crkve Sv. Marte u Bijaćima, Starohrvatska prosvjeta, III. s., 26/1999., Split, 2004, 265-286; Isti, Trogirska klesarska radionica u reljefima iz svete Marte u Bijaćima, u: Klesarstvo u službi evangelizacije, Split 2015, 267-294. Poznavanju tzv. Trogirske klesarske radionice kasnije je znatno pridonio Ivan Josipović u članku iz 2011. te u svojem doktorskom radu iz 2013. godine. Vidi: I. Josipović, Prilog Trogirskoj klesarskoj radionici, Ars Adriatica, 1, Zadar, 2011, 97-107; Isti, Predromanički reljefi na teritoriju sklavinije Hrvatske između Zrmanje i Krke do kraja 9. stoljeća, doktorski rad, 1. dio, Zagreb, 2013, 85-102.

U kontekstu proučavanja predromaničke kamene plastike Trogira i njegove bliže okolice treba istaknuti rad: T. Burić, Predromanička skulptura u Trogiru, Starohrvatska prosvjeta, 3. s., 12, Split, 1982, 127-159. U tom članku, kao vrsni poznavatelj navedene tematike, autor se dotiče i povezanosti te plastike sa širim područjem, prvenstveno sjevernom Dalmacijom.

11 I. Josipović, Predromanički reljefi na teritoriju sklavinije Hrvatske, 1. i 2. dio, 97-98, T. XXII-XXIII. 
Za ulomak arhitrava ograde svetišta (slika 10) s ostatkom posvetnog natpisa [...sancta]E MARIE[...] pojedini autori već su naslutili da bi on mogao pripadati tzv. Trogirskoj klesarskoj radionici, no - s obzirom na to da se radilo o jedinom tada poznatom ulomku kamene plastike iz crkve sv. Stefana u Golubiću - nisu se usudili to decidirano i tvrditi. ${ }^{13}$ Naprijed opisani i obrađeni nalazi ulomaka pluteja i pilastra (slike 6, 8 i 9) kao i analogni primjerci arhitrava iz Kljaka, Pađena, Brnaza, šibenskog Donjeg polja polja i Bijaća ${ }^{14}$ potvrda su da je zaista riječ o toj klesarskoj radionici.

Ne možemo zasad decidirano tvrditi da tzv. Trogirskoj klesarskoj radionici pripada i zasad nedefinirani ulomak kamene plastike (slika 12), no s obzirom na izgled ukrasa pletenice na njemu, velika je mogućnost da se i ondje radi o toj radionici.

Drugi pronađeni ulomak arhitrava ograde svetišta, nažalost, izuzetno oštećen i naknadno izgubljen (slika 11), pripada sasvim drugoj klesarskoj radionici i vremenu nastanka. Način izrade njegovih kuka i troprutih petlji ispod njih upućuje na $z$ v. Benediktinsku klesarsku radionicu iz vremena kneza Branimira, odnosno zadnju četvrtinu 9. stoljeća. ${ }^{15}$ Najbliže analogije arhitravu iz Golubića nalazimo među primjercima arhitravâ s posvetnim napisom kneza Branimira koji potječe s nalazišta Otres kod Bribira ${ }^{16}$ te manjem ulomku arhitrava s nalazišta Biskupija - Stupovi. ${ }^{17}$

13 Usp. N. Jakšić, Klesarstvo u službi evangelizacije, u: Hrvati i Karolinzi - Rasprave i vrela, (ur.) Ante Milošević, Split, 2000, 206; V. Delonga - N. Jakšić - M. Jurković, Arhitektura, skulptura i epigrafika karolinškog doba u Hrvatskoj, Split, 2001, 46; N. Jakšić, Reljefi Trogirske klesarske radionice, 271; I. Josipović, Prilog Trogirskoj klesarskoj radionici, 105, bilj. 2; Isti, Predromanički reljefi na teritoriju sklavinije Hrvatske, 1. dio, 88, bilj. 229; N. Jakšić, Trugirska klesarska radionica u reljefima iz svete Marte, 273.

Usp. I. Josipović, Predromanički reljefi na teritoriju sklavinije Hrvatske, 1. i 2. dio, 90-92, T. XXVIII-XXIX.

Naziv Benediktinska klesarska radionica iz vremena kneza Branimira u potpunosti je definirao i inauguriro Nikola Jakšić tijekom izložbi Hrvati i Karolinzi 2000. te Bizantini, Croati, Carolingi 2001. godine, u radovima V. Delonga - N. Jakšić - M. Jurković, Arhitektura, skulptura i epigrafika karolinškog doba u Hrvatskoj, 48-52, i N. Jakšić, Scultura e liturgia, u: Bizantini, Croati, Carolingi. Alba e tramonto di regni e imperi, (ur.) Carlo Bertelli et alii, Milano, 2001, 189-196. Ideja o povezivanju dijela predromaničke kamene plastike iz vremena kneza Branimira u posebnu homogenu skupinu nastala je dvadesetak godina ranije kao ideja Ive Petriciolija i Nikole Jakšića u sljedećim radovima: I. Petricioli, Oko datiranja umjetniçkih spomenika ranoga srednjeg vijeka, u: Gunjaĉin zbornik, (ur.) Ivan Erceg et alii, Zagreb, 1980., 115-118, i N. Jakšić, Srednjovjekovni zabati oltarskih pregrada u Dalmaciji (od Zrmanje do Cetine). Stilsko-tipološka analiza, magistarski rad, Zagreb, 1980, 36-41, 98-103, kat. br. 29-36. Poznavanju navedene radionice dodatno je pridonio Ivan Josipović u svojoj disertaciji Predromanički reljefi na teritoriju sklavinije Hrvatske, 1. dio, 169-191.

I. Josipović, Predromanički reljefi na teritoriju sklavinije Hrvatske, 1. i 2. dio, 181-182, 481-482, T. XLIX 8-9, T. OTRES II, 9a-9c. U tom je radu na str. 482 navedena i sva dotad objavljena literatura o tim nalazima, pa je ovdje pojedinačno ne spominjem. 


\section{ZAKLJUČAK}

Nalazi kamenog crkvenog namještaja pronađeni pri uređenju crkve sv. arhiđakona Stefana u Golubiću kod Knina tijekom radova na njezinoj obnovi 2009. - 2015. izuzetno su važni za poznavanje vremena njezina nastanka i faza obnove. Tim je nalazima potvrđena dosadašnja pretpostavka da je riječ o građevini nastaloj u ranokršćanskom vremenu, koja je tijekom ranosrednjovjekovnog vremena doživjela preinake. Njezina prva faza obnove iz koje potječe većina pronađenih ulomaka veže se uz karolinško razdoblje, kada dobiva novi kameni namještaj koji se radionički može povezati s tzv. Trogirskom klesarskom radionicom, odnosno prvom četvrtinom 9. stoljeća. Tada su, po svoj prilici, nastale i njezine druge građevinske preinake, vezane uz pročelje i nastanak zvonika. Druga predromanička faza zastupljena je tek s jednim ali vrlo dragocjenim nalazom, ulomkom grede ograde svetišta koji se može povezati s tzv. Benediktinskom klesarskom radionicom iz vremena kneza Branimira i zadnjom četvrtinom 9. stoljeća. Ta saznanja navode na činjenicu da je $u$ tom trenutku to mogao postati i vladarski posjed.

Izuzetno plodan i strateški važan širi prostor Golubića, odnosno spomenutog srednjovjekovnog sela Butina Vas, još od doseljenja za Hrvate je imao izuzetno značenje, a o tome svjedoči i glasoviti nalaz zlatnoga nakita s položaja Stolića njiva. ${ }^{18}$ To je trajalo i tijekom cijelog razdoblja ranosrednjovjekovne hrvatske države, a naravno i kasnije, sve do ratova s Osmanlijama, nakon kojih se u potpunosti promijenila svekolika slika toga područja. U tom kontekstu treba promatrati i crkvu na prostoru današnje crkve sv. Stefana koja je u ranom srednjem vijeku, sudeći prema pronađenom ulomku posvetnog natpisa [...sancta]E MARIE[...], bila posvećena Bogorodici, dok je suzaštitnik mogao biti sv. Stjepan, kao što je to slučaj na obližnjem lokalitetu Biskupija - Crkvina. ${ }^{19}$ Velika je vjerojatnost da je taj titular baština ranokršćanskog vremena, a zadržan je i nakon prelaska crkve pod pravoslavnu jurisdikciju.

Prostor crkve sv. Stefana u Golubiću nikada nije bio arheološki istraživan. Na ovome mjestu obrađeni i objavljeni nalazi nesumnjivo su pokazali da se radi o vrlo važnom arheološkom i povijesnom spomeniku, pa se nadam da će se u budućnosti iznaći sredstva za arheološka istraživanja unutrašnjosti i dijela okoliša crkve poštujući, naravno, činjenicu da se radi o živućem sakralnom prostoru i mjesnom groblju.

18 S. Gunjača, Trogodišnji rad Muzeja hrvatskih arheoloških spomenika (1955., 1956. i 1957. godine), Starohrvatska prosvjeta, III. s., 7, Zagreb, 1960, 276; M. Petrinec, Groblja od 8. do 11. stoljeća na području ranosrednjovjekovne hrvatske države, Split, 2009, 33, T. 80; Ista, O nakitu iz Golubića i ženskoj nošnji iz razdoblja 8. i prve polovine 9. stoljeća, Starohrvatska prosvjeta, III. s., 46, Split, 2019, 45-166.

19 Treba naglasiti da to ne može biti crkva koja se i izvorima spominje kao crkva Sancti Stephani in suburbio, kako to smatra T. Marasović (usp. bilj. 7 u ovom radu), jer prostor Golubića nije podgrađe Knina već položaj u njegovoj okolici. 


\section{Summary}

\section{Finds of Stone Church Furniture from the Church of St. Stephan in Golubić near Knin}

In this paper, the author originally announces and analyses fragments of stone church furniture from the Church of St. Stephan in Golubić near Knin, discovered during restoration works conducted in the years 2009, 2010, 2014 and 2015. From this church, only one fragment of the architrave of the enclosure of the sanctuary, approximately dated to the $9^{\text {th }}$ century, has been known so far. The six newly discovered fragments offer a possibility for more accurate dating of the creation and restoration thereof. The earliest phase, connected with Early Christianity, was undoubtedly followed by two pre-Romanesque phases, out of which the first one is connected to the so-called Trogir stonemason's workshop and the first quarter of the $9^{\text {th }}$ century, whereas the second may be linked to the so-called Benedictine stone-mason's workshop of Duke Branimir's era, i.e. the final quarter of the $9^{\text {th }}$ century.

Keywords: Golubić; church of St. Stephan; Trogir stone-mason's workshop; Benedictine stone-mason's workshop of Duke Branimir's era; Early Christianity; pre-Romanesque art. 
